\title{
Diel vertical migration and feeding of Sagitta friderici and Sagitta tasmanica in the southern Benguela upwelling region, with a comment on the structure of the guild of primary carnivores
}

\author{
Mark J. Gibbons* \\ Marine Biology Research Institute, Dept of Zoology, University of Cape Town, Rondebosch 7700, Cape Town, South Africa \\ and \\ Sea Fisheries Research Institute, Private Bag X2, Roggebaai 8012, Cape Town, South Africa
}

\begin{abstract}
Diel vertical migration of the 2 most common chaetognaths (Sagitta friderici and S. tasmanica) in the southern Benguela was investigated at two $72 \mathrm{~h}$ stations during summer 1991. Feeding was examined over $24 \mathrm{~h}$ windows in these data sets. Both species exhibited diel vertical migration, although this was not obvious from changes in the mean depth occupied by night and day. Both species fed maximally at night in the upper layers before moving to deeper water to digest their food. Their diets were composed almost exclusively of copepods, and size preferences were exhibited by each species. The chaetognaths were segregated along a number of niche axes: viz. depth, time of maximal feeding and diet itself. It is suggested that competition between chaetognaths may have been high during periods of prolonged quiescence and mismatch, and that resource partitioning in a persistent guild has evolved to mitigate this. This alters the concept of zooplankton communities in upwelling regions as being exclusively physically structured. Although comparisons between the diets of chaetognaths and of the other first-order carnivore, Euphausia lucens, reveal similar partitioning of copepod prey, this structure cannot be interpreted in terms of historic competition but rather reflects differential mechanisms of resource acquisition.
\end{abstract}

KEY WORDS: Chaetognatha $\cdot$ Feeding Diel vertical migration - Resource partitioning Zooplankton community structure - Southern Benguela upwelling region

\section{INTRODUCTION}

Chaetognaths are generally the most numerous and conspicuous carnivores in samples of marine zooplankton and on average constitute $30 \%$ of zooplankton biomass (Reeve 1970). Previously considered as voracious, they are now known to be quite selective predators with little direct effect on zooplankton standing stocks (see references in Feigenbaum \& Maris 1984, Feigenbaum 1991), except under conditions of low environmental productivity (Kimmerer 1984, Øresland 1990). Because copepods make up the bulk of chaetognaths' diet (Feigenbaum \& Maris 1984), they

\footnotetext{
- Please direct all correspondence to the Roggebaai address
}

can be considered to constitute one of the most important 'primary carnivores' in pelagic marine ecosystems (microheterotrophs excepted). Chaetognaths, in turn, fall prey to just about all other pelagic carnivores, including fish (e.g. James 1987).

Three species of chaetognath are to be found in the inshore waters of the southern Benguela, all of which can be classified as either epi- or shallow mesopelagic. Sagitta friderici (or Parasagitta friderici, see Bieri 1991) is typically the most abundant (Heydorn 1959) and can at times make up $90 \%$ of chaetognath numbers (Venter 1969). It is a cold-water, neritic species that has a somewhat disjointed distribution, occurring all the way up the west coasts of both the American and African continents (Pierrot-Bults \& Nair 1991). The other common species, Sagitta tasmanica (= Serratosagitta tas- 
manica), is generally less numerous than $S$. friderici in the southern Benguela, but is abundant in the northern Benguela (Venter 1969). It has a circumantarctic distribution, generally occurring at latitudes higher than $40^{\circ} \mathrm{S}$, although its range does extend northward up the Atlantic coast of Africa to south of the bulge (PierrotBults \& Nair 1991). There is a northern hemisphere population of $S$. tasmanica centred on the NE Atlantic which extends as far south as the upwelling region along the north African coast (Thiriot 1978), and another has recently been identified in the Middle Atlantic Bight (Grant 1991). The least abundant of the 3 locally common species, Sagitta minima (= Mesosagitta minima), is a circumglobal, warmwater oceanic species which is largely confined to latitudes between $40^{\circ} \mathrm{N}$ and $40^{\circ} \mathrm{S}$ (Pierrot-Bults \& Nair 1991). It is usually found at the shelf edge in the southern Benguela and occurs inshore under periods of blue water intrusion (Heydorn 1959).

Earlier studies of Sagitta friderici and S. tasmanica have concentrated on their diet and diel vertical migration (DVM) (Stuart \& Verheye 1991, Gibbons 1992, Gibbons \& Stuart in press) in isolation of each other. Direct comparative studies have not been made and it has not been possible to make any comments on the structure of the guild of first-order carnivores. Here, the diel vertical migration and feeding of both species of chaetognath are compared at 2 stations in the southern Benguela upwelling region and these in turn are compared with the facultative carnivore Euphausia lucens.

\section{MATERIALS AND METHODS}

Sample collection. During February 1991, 2 stations along a transect running off the Olifants River mouth, South Africa $\left(31^{\circ} 37^{\prime} \mathrm{S}, 18^{\circ} 18^{\prime} \mathrm{E}\right)$ were intensively sampled over $72 \mathrm{~h}$. The inner station (inshore) was in $65 \mathrm{~m}$ of water and was 2 nautical miles from the coast. It was sampled between 22:00 h on 16 February and 23:00 h on 19 February 1991. The other station (midshelf) was situated in $255 \mathrm{~m}$ of water and was 62 nautical miles from the coast. It was sampled between 10:00 h on 20 February and 23:00 h on 22 February 1991.

At each station, a conductivity-temperature-depth rosette sampler was cast to the bottom every $6 \mathrm{~h}$ to provide profiles of temperature and salinity. Water samples taken at $10 \mathrm{~m}$ intervals in the upper $100 \mathrm{~m}$ were analysed immediately for chlorophyll a. Zooplankton samples were collected using a $200 \mu \mathrm{m}$ mesh $1 \mathrm{~m}^{2}$ multiple opening-closing rectangular midwater trawl (RMT $1 \times 6$ ), which was towed obliquely at 2 knots over 5 depth strata from just above the bottom to the sur- face. These strata were approximately $65-50,50-30$, $30-20,20-10,10-0 \mathrm{~m}$ at the inshore station, and $250-100,100-60,60-40,40-20$ and $20-0 \mathrm{~m}$ at the midshelf station. Flow was estimated by means of an electronic flowmeter mounted above the mouth of the net, and $100 \%$ filtration efficiency was assumed for the tows, which were of short duration for each net. On retrieval, the contents of each net were preserved in $4 \%$ buffered $\left(\mathrm{CaCO}_{3}\right)$ saline formalin for examination in the laboratory. Zooplankton were collected every ca $2 \mathrm{~h}$ throughout the night (ca 20:00 to 06:00 h) and every ca $4 \mathrm{~h}$ during the day. Gear failure at 03:00 $\mathrm{h}$ on 19 February 1991, however, meant that sampling was suspended for $6 \mathrm{~h}$.

Sample processing. In determining vertical distribution and abundance, all chaetognaths were counted from each sample. When collections were large, subsamples were taken using a Folsom splitter and a minimum of 50 individuals were counted. Data were standardised to numbers per $\mathrm{m}^{3}$ and per $\mathrm{m}^{2}$ using net flowmeter data.

The total body length (excluding tail fin) of 50 randomly selected individuals from each sample was measured and the stage of maturity determined according to the development of the ovaries (Thomson 1947).

Copepod consumption by both species of chaetognath was determined over a single $24 \mathrm{~h}$ period at each station (17 to 18 February 1991 inshore and 20 to 21 February 1991 at the midshelf station) following the method described by Gibbons (1992). In short, the hind guts of 50 measured individuals of each species from each sampling time and depth were dissected out and broken open in glycerine on glass slides. The contents were examined at $160 \times$ magnification for copepod mandibles, which were counted, measured and identified to species. Samples with fewer than 20 individuals were ignored: when 20 to 50 individuals were collected, the whole sample was analysed if possible. In each sample the proportion of the population containing food in their guts, the food containing ratio (FCR = no. chaetognaths containing food/total no. chaetognaths $\times 100$ ), was calculated as was the mean number of prey items per chaetognath $(\mathrm{NPC}=$ total no. prey items/total no. chaetognaths). Copepod mandible widths were converted to copepod prosome lengths and widths using the equations in Stuart \& Pillar (1990) and Stuart \& Verheye (1991).

In order to relate the diet of chaetognaths to the ambient food environment, copepod abundances and distribution were determined over the same two $24 \mathrm{~h}$ periods. These data will not be presented or discussed in detail, as they only represent selected portions of the larger $72 \mathrm{~h}$ data sets, which are yet to be fully analysed and will be published elsewhere. All copepods were counted by species from $2 \mathrm{ml}$ subsamples taken with a 
piston pipette (see Peterson et al. 1990) from each depth stratum at every other sampling interval ( 3 day, 3 night). All developmental stages are here lumped together, because while there is undoubtedly a correlation between the dimensions of copepod mandibles (recovered from chaetognath guts) and developmental stage, it is not at present available.

The estimation of prey selection by a predator in a 3-dimensional environment is fraught with difficulties, not least of which is the problem of determining where the predator has been feeding (see approaches taken by Pearre 1973, 1974, Stuart \& Verheye 1991, Gibbons 1992). In this study no attempt has been made to tie together migration paths and distances over the gut passage time with changes in the ambient prey field over those distances (as Gibbons 1992). Rather, comparisons have been made using a weighted estimate of diet at night, i.e. the proportional composition of the diet at any depth has been weighted by the proportion of the chaetognath population at that depth, and the total summed over the depth ranges.

Statistical analysis. To determine day/night differences in vertical distribution both between and within species, mean day and night time depths were compared using single-factor Kruskal Wallis analyses (Zar 1984). This non-parametric statistical test was also used to examine day/night differences in abundance, and to determine changes in chaetognath feeding over time as well as to assess the significance of depth on gutcontents (NPC). Kolmogorov-Smirnov 1- and 2-sample tests (Sokal \& Rohlf 1981, Zar 1984) were performed on selected data in order to (1) compare the size distributions of chaetognath 'populations' between stations and depths, (2) determine whether either species of chaetognath selected components of its diet from the ambient prey spectra, and (3) compare the size distributions of prey eaten between the 2 chaetognaths. Null hypotheses were (respectively) that (1) populations have the same size distribution irrespective of station and depth, (2) each prey species and size class of prey occurs in the diet of each chaetognath species at the same proportion as it occurs in the water column and (3) that the diet by prey size of both species of chaetognath were the same. Differences between data were considered significant at the $95 \%$ level.

\section{RESULTS}

Fuller descriptions of the physical environment at the 2 stations during February 1991 are provided by Gibbons (1993). In short, a pronounced thermocline existed between 5 and $25 \mathrm{~m}$ at the inshore station, where chlorophyll maxima were observed between 10 and $20 \mathrm{~m}$. At the midshelf station, by contrast, the thermocline was weak and the chlorophyll concentration decreased from the surface. Surface chlorophyll levels at the inshore station (13.31 to $55.04 \mathrm{\mu g} \mathrm{l}^{-1}$ ) were an order of magnitude greater than at the midshelf station (1.46 to $4.57 \mathrm{\mu g} \mathrm{l}^{-1}$ )

\section{Copepods: abundance and distribution}

Probably owing to the combination of adult and copepodite data, there was little difference in the vertical distribution of copepods between sampling intervals at night. All the nocturnal collections are thus considered together as replicates. Likewise with the diurnal samples, so that the data are considered here in terms of day and night only. A fuller description and figure can be found in Gibbons (1993).

Although copepods were more or less evenly distributed throughout the water column at the inshore station, densities were highest in the upper $20 \mathrm{~m}$ (day, $26617 \mathrm{~m}^{-3}$; night, $7391 \mathrm{~m}^{-3}$ ) and reached minimum values between 50 and $65 \mathrm{~m}$ (day, $3378 \mathrm{~m}^{-3}$; night, $3832 \mathrm{~m}^{-3}$ ). Oithona spp. dominated the copepod assemblage throughout the water column (Table 1) and reached maximum densities in the upper $20 \mathrm{~m}$ (day, $21260 \mathrm{~m}^{-3}$ ). Metridia lucens was more common at depth than near the surface, while Centropages brachiatus was mostly restricted to the upper $20 \mathrm{~m}$ $\left(1048 \mathrm{~m}^{-3}\right)$ and occurred at very low densities below $50 \mathrm{~m}$ (night, $7.1 \mathrm{~m}^{-3}$ ).

Copepods were less abundant at the midshelf station, and total densities decreased markedly from the upper $20 \mathrm{~m}$ (day, $9114 \mathrm{~m}^{-3}$; night, $9216 \mathrm{~m}^{-3}$ ) to a minimum at between 100 and $250 \mathrm{~m}$ (day, $83 \mathrm{~m}^{-3}$; night, $160 \mathrm{~m}^{-3}$ ). Oithona spp. were less common at the midshelf than the inshore station, and communities in both the surface and deep-water layers were dominated by small calanoids (Paracalanus spp. and Ctenocalanus vanus) (Table 1). Metridia lucens was again more common in deep than shallow water layers, where it comprised $27 \%$ of total copepods between 100 and $250 \mathrm{~m}$. Centropages brachiatus and large calanoids (Calanoides carinatus and Calanus agulhensis) were mostly confined to the

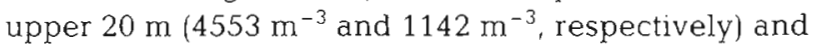
represented $<5 \%$ of the copepods between 100 and $250 \mathrm{~m}$ ( 5.8 and $1.5 \mathrm{~m}^{-3}$ respectively).

The shallow distribution of Centropages brachiatus makes it a useful tracer of surface feeding chaetognaths (as Pearre 1973, Gibbons 1993).

\section{Sagitta friderici}

Sagitta friderici comprised approximately $53 \%$ of chaetognaths at the inshore station and $8 \%$ of those at 
Table 1. Sagitta friderici and S. tasmanica. Distribution of copepod species (\% of numbers) in ambient food environment and chaetognath guts in surface and deep-water layers. Nocturnal samples combined; total unity not required since species not eaten (e.g. Rhincalanus nasutus) not included. Sf: S. friderici; St: S. tasmanica; -: too few data

\begin{tabular}{|c|c|c|c|c|c|c|}
\hline \multirow[t]{2}{*}{ Taxon } & \multicolumn{3}{|c|}{ Inshore } & \multicolumn{3}{|c|}{ Midshelf } \\
\hline & Ambient & Sf gut & St gut & Ambient & Sf gut & St gut \\
\hline & \multicolumn{3}{|c|}{$0-20 \mathrm{~m}$ depth } & \multicolumn{3}{|c|}{$0-20 \mathrm{~m}$ depth } \\
\hline Oithona spp. & 41.0 & 29.1 & 17.6 & 12.2 & 12.1 & 0 \\
\hline Small calanoids & 28.9 & 42.8 & 76.5 & 46.1 & 9.8 & 5.5 \\
\hline Centropages brachiatus & 10.7 & 21.1 & 0 & 33.9 & 65.1 & 92.4 \\
\hline Metridia lucens & 4.5 & 0.6 & 0 & 0.4 & 0 & 0 \\
\hline \multirow[t]{2}{*}{ Large calanoids } & 3.7 & 6.4 & 5.9 & 7.3 & 13.0 & 2.1 \\
\hline & \multicolumn{3}{|c|}{ 50-65 m depth } & \multicolumn{3}{|c|}{$100-250 \mathrm{~m}$ depth } \\
\hline Oithona spp. & 58.4 & 23.6 & 10.7 & 18.1 & - & 3.2 \\
\hline Small calanoids & 27.1 & 50.0 & 85.7 & 51.0 & - & 6.4 \\
\hline Centropages brachiatus & 0.3 & 13.2 & 0 & 3.2 & - & 71.3 \\
\hline Metridia lucens & 12.3 & 5.3 & 0 & 26.9 & - & 0 \\
\hline Large calanoids & 1.7 & 7.9 & 3.6 & 0.8 & - & 19.1 \\
\hline
\end{tabular}

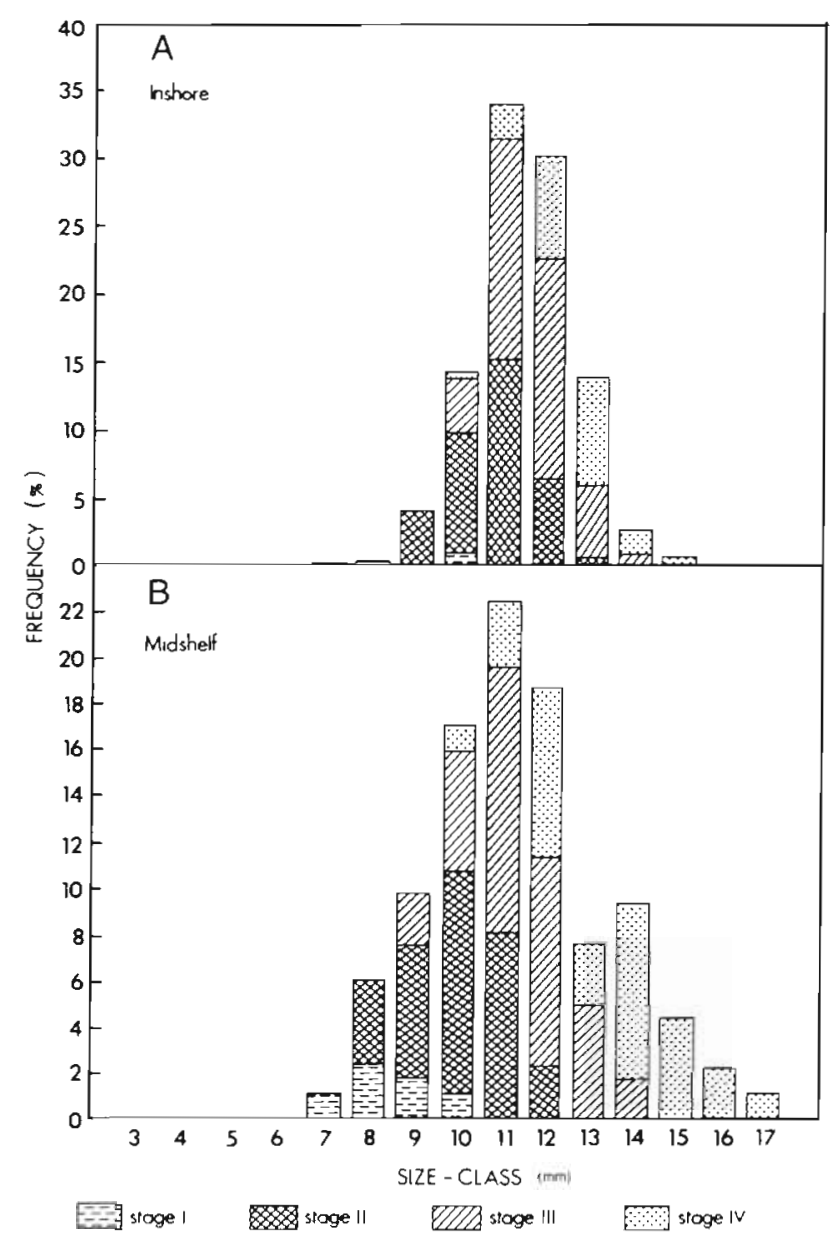

Fig. 1. Sagitta friderici. Length: frequency (as percent) plots of populations at the $(A)$ inshore and (B) midshelf stations. The relationship between chaetognath length and the stage of ovarian development is superimposed the midshelf station during the period of this study. S. tasmanica represented $43 \%$ and $39 \%$ at each station respectively, and the balance was made up largely by $S$ minima.

Populations of Sagitta friderici at both the inshore and midshelf stations exhibited a similar unimodal size-frequency distribution, with adults reaching a maximum size of approximately $17 \mathrm{~mm}$ (Fig. 1). These distributions resemble those presented by Stuart \& Verheye (1991) and Gibbons \& Stuart (in press). There was no significant difference in the size structure of samples with depth at either station $(p>0.05)$ and this did not change over time.

Sagitta friderici was generally much more abundant at the inshore than midshelf station (see depthintegrated abundances in Fig. 2), which is hardly surprising considering the neritic nature of this species (Pierrot-Bults \& Nair 1991). There were no significant differences in chaetognath abundance over the diel cycle at either of the 2 stations, indicating that individuals were not migrating beyond the sampling depth. Although this should make for easy interpretation of net-collected samples, examination of the vertical profiles presented in Fig. 2 would suggest that DVM is anything but clear at either station. And certainly, there was no significant difference in the mean depth occupied by daytime $(30.95 \pm 2.44 \mathrm{~m}$ inshore, $16.59 \pm 2.38 \mathrm{~m}$ midshelf) or night-time populations $(23.53 \pm 1.63 \mathrm{~m}$ and $18.06 \pm 2.59 \mathrm{~m}$ respectively) $(p<0.01)$. If the vertical distribution of $S$. friderici between 17 and 18 February at the inshore station is examined in more detail (Fig. 3A), however, it is clear that the population was not static. Indeed, there was a pronounced movement into the surface $20 \mathrm{~m}$ at both dusk and dawn indicative of 
으요 용 n
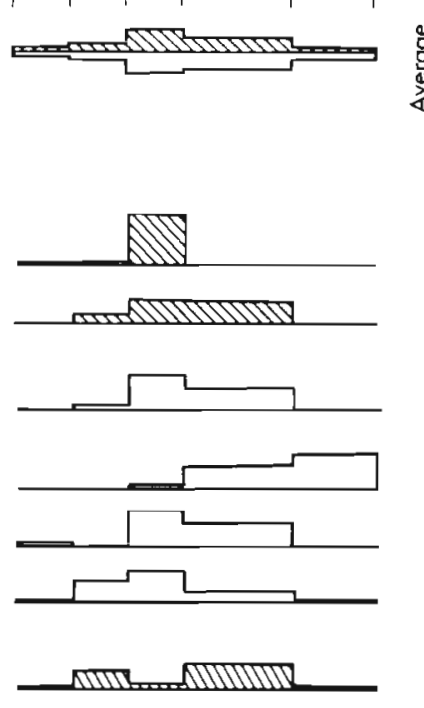

$00000000111 / 8$
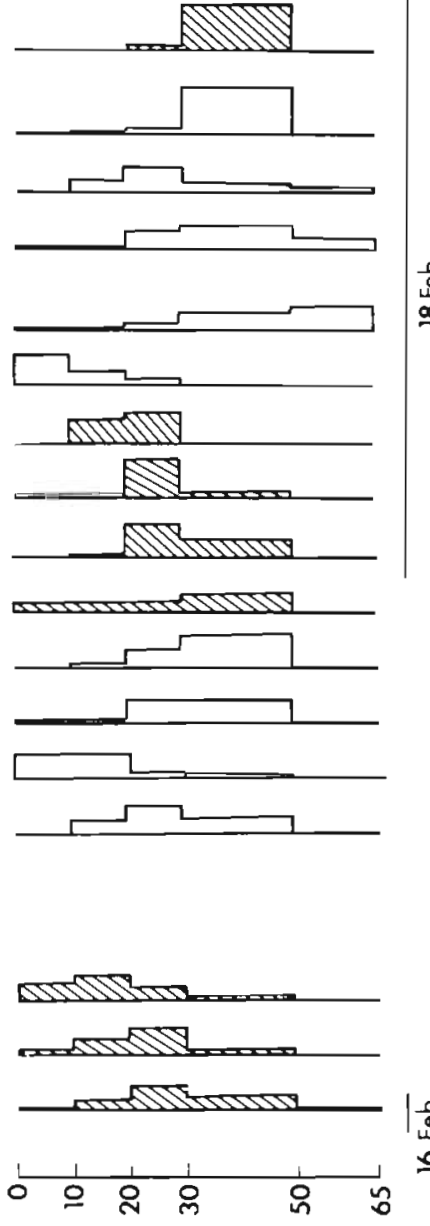

흠 $\bar{E}$

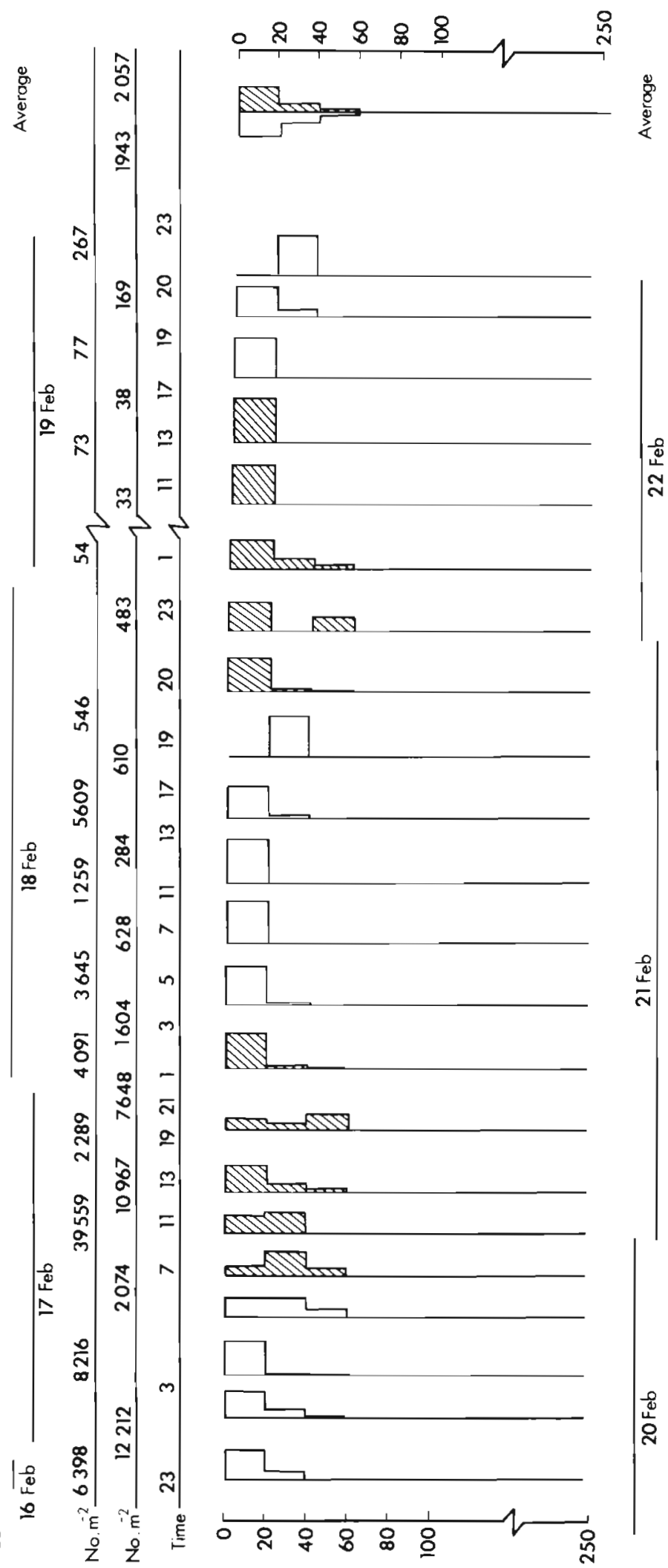

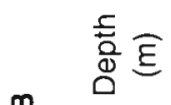

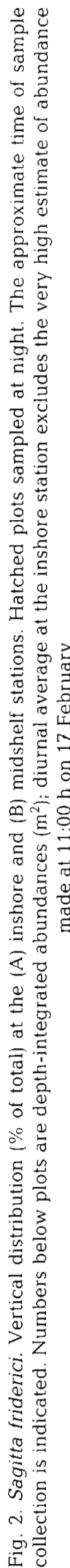



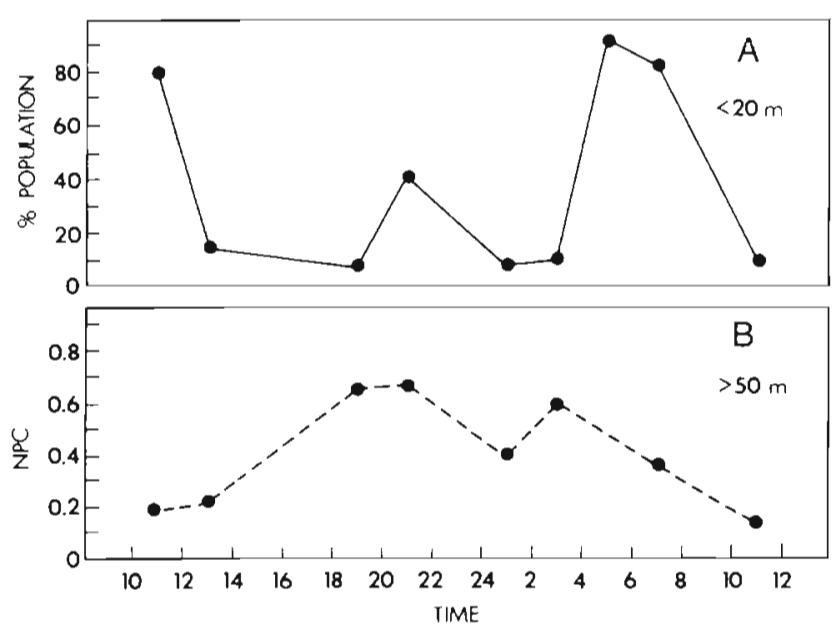

Fig. 3. (A) Proportion of Sagitta friderici in the upper $20 \mathrm{~m}$ at the inshore station between 17 and 18 February 1991 (B) Mean number of copepods per chaetognath collected from deep water (>50 m) over the same period

Table 2. Sagitta friderici and S. tasmanica. Mean (SE) prey size $(\mathrm{mm})$ by length class. Data are from the inshore and midshelf stations combined

\begin{tabular}{|cll|}
\hline $\begin{array}{c}\text { Chaetognath } \\
\text { length }(\mathrm{mm})\end{array}$ & S. friderici & S. tasmanica \\
\hline 7 & $0.284(-)$ & \\
8 & $0.538(0.041)$ & $0.548(0.063)$ \\
9 & $0.573(0.006)$ & $0.562(0.071)$ \\
10 & $0.586(0.019)$ & $0.620(0.065)$ \\
11 & $0.646(0.016)$ & $0.776(0.091)$ \\
12 & $0.702(0.017)$ & $0.719(0.063)$ \\
13 & $0.805(0.027)$ & $1.022(0.095)$ \\
14 & $0.844(0.046)$ & $1.030(0.042)$ \\
15 & $1.022(0.113)$ & $1.038(0.020)$ \\
16 & $1.111(0.227)$ & $1.073(0.019)$ \\
17 & & $1.066(0.024)$ \\
\hline
\end{tabular}

Table 3. Sagitta friderici $(S f)$ and $S$. tasmanica (St). Frequency $(\%)$ of multiple prey items in chaetognath diets at the inshore and midshelf stations

\begin{tabular}{|ccrrr|}
\cline { 5 - 5 } $\begin{array}{l}\text { No. of } \\
\text { prey }\end{array}$ & \multicolumn{2}{c}{ Inshore } & \multicolumn{2}{c|}{ Midshelf } \\
\hline 1 & Sf & St & Sf & St \\
2 & 65.9 & 94.3 & 87.3 & 61.9 \\
3 & 19.9 & 4.7 & 9.9 & 18.6 \\
4 & 7.1 & 1.0 & 2.8 & 9.8 \\
5 & 3.2 & - & - & 5.2 \\
6 & 2.4 & - & - & 2.3 \\
7 & 1.0 & - & - & 1.0 \\
8 & 0.2 & - & - & 0.5 \\
9 & - & - & - & 0.5 \\
& 0.2 & - & - & 0.3 \\
\hline
\end{tabular}

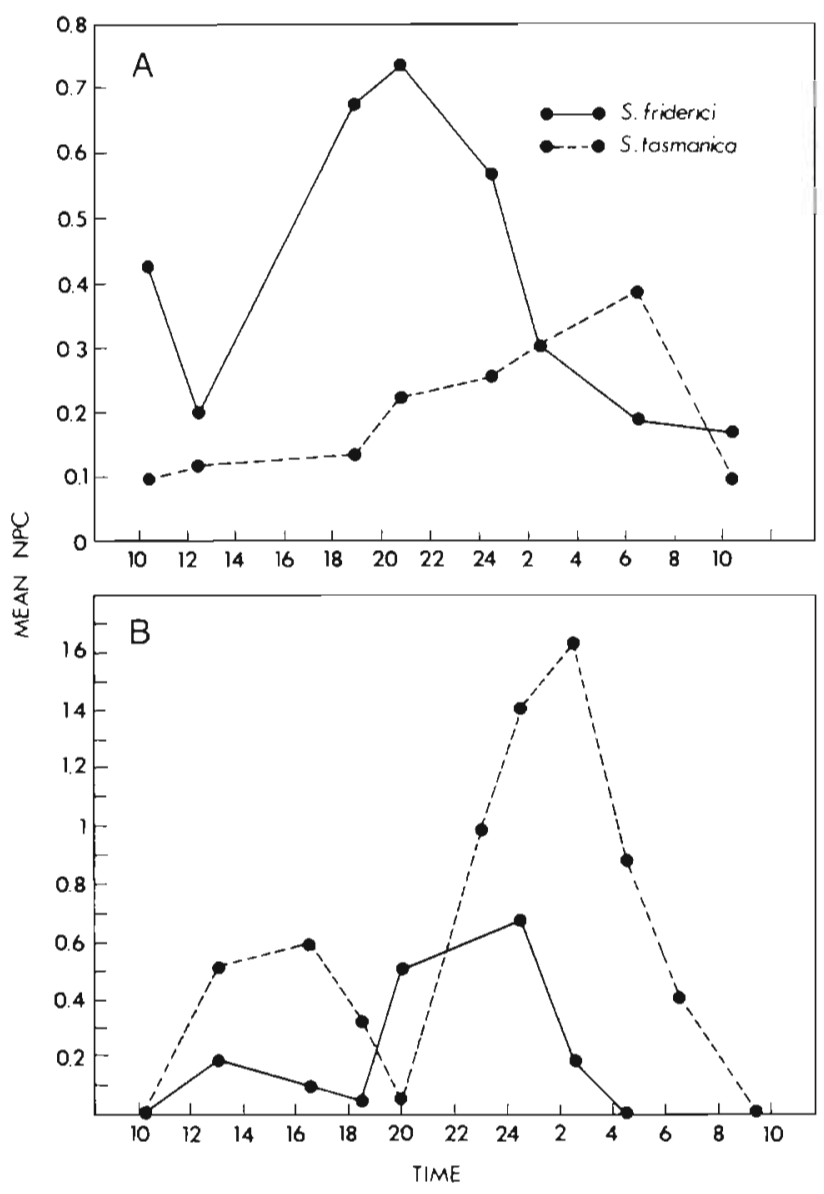

Fig. 4. Sagitta frederici and S. tasmanica. Mean number of copepods per chaetognath (NPC) at the (A) inshore and (B) midshelf stations during 17 to 18 February 1991. These data are calculated as the product of means at each depth strata by proportion of the population at each strata (thus no error bars)

midnight sinking (see also Stuart \& Verheye 1991). No clear patterns of movement were observed at the midshelf station, either because densities were too low or the sampling scales were of the wrong resolution.

Copepods formed over $98 \%$ of the diet of Sagitta friderici and cannibalism occurred in only 6 of the 2817 specimens examined at the inshore station. Cannibalism was not observed at the midshelf station possibly because too few animals (186) were examined. This generally low incidence of cannibalism is in agreement with the observations of Stuart \& Verheye (1991) and Gibbons \& Stuart (in press). There was no relationship between the number of prey eaten and chaetognath length but there was a positive correlation between the lengths of predator and prey (Table 2 ). The mean number of copepods eaten by chaetognaths at the inshore station was greater than that at the midshelf station, 
Table 4. Sagitta friderici and S. tasmanica. Mean number (SE) of prey items per chaetognath (NPC) per depth stratum, by day and night. All data per stratum are averaged (day and night separately). -NPC at dusk and dawn significantly different from those at other diurnal sampling intervals (see Fig. 3). -: too few data

\begin{tabular}{|lccccc|}
\hline \multirow{2}{*}{$\begin{array}{l}\text { Depth } \\
\text { stratum }\end{array}$} & \multicolumn{2}{c}{ S. friderici } & \multicolumn{2}{c}{ S. tasmanica } \\
Inshore & & & Night & Day & Night \\
$0-20 \mathrm{~m}$ & 0.299 & 0.632 & 0.286 & 0.449 \\
& $(0.053)$ & $(0.053)$ & $(0.125)$ & $(0.077)$ \\
$20-50 \mathrm{~m}$ & 0.213 & 0.437 & - & 0.169 \\
& $(0.057)$ & $(0.067)$ & - & $(0.043)$ \\
$50-65 \mathrm{~m}$ & $0.320^{\circ}$ & 0.382 & 0.189 & 0.238 \\
& $(0.038)$ & $(0.058)$ & $(0.019)$ & $(0.024)$ \\
Midshelf & & & & \\
$0-40 \mathrm{~m}$ & 0.139 & 0.663 & 0.522 & 1.378 \\
& $(0.058)$ & $(0.081)$ & $(0.083)$ & $(0.101)$ \\
$40-100 \mathrm{~m}$ & 0.050 & 0.489 & 0.368 & 1.056 \\
& $(0.050)$ & $(0.080)$ & $(0.045)$ & $(0.106)$ \\
$100-250 \mathrm{~m}$ & - & - & 0.400 & 0.562 \\
& & & $(0.244)$ & $(0.085)$ \\
\hline
\end{tabular}

with up to 9 prey items being recovered from a single individual. Single prey items otherwise accounted for $66 \%$ and $87 \%$ of the diet of $S$. friderici at each station respectively (Table 3 ).

Sagitta friderici had the remains of prey in its gut throughout the $24 \mathrm{~h}$ periods of detailed investigation at both stations (Fig. 4). And, despite the absence of any statistically clear DVM, the number of prey recovered from chaetognath guts was higher during the night $10.51 \pm 0.03$ per chaetognath inshore, $0.59 \pm 0.06$ midshelf) than during the day $(0.29 \pm 0.03$ inshore, $0.11 \pm$ 0.04 midshelf). While there was no correlation between the number of prey per chaetognath and the depth of sample collection during the day (and at night at the midshelf station; Table 4), individuals sampled in the upper $20 \mathrm{~m}$ of the inshore station at night had more prey in their guts than those collected in deep water (Table 4). Interestingly though, more copepods were recovered from chaetognath guts at dawn and dusk from $S$. friderici in deep water than at other times during the hours of daylight at the inshore station (Fig. 3B), and this is in agreement with the movement of superficially feeding individuals into deep water (Fig. 3A).

Sagitta friderici ate a wide size range of copepods at both stations $(0.3$ to $2.2 \mathrm{~mm}$ prosome length, inshore; 0.3 to $1.4 \mathrm{~mm}$, midshelf). At both stations the size distribution of copepods consumed was bimodal (Tables 5 $\& 6$ ): the smaller peak occurring at $0.3 \mathrm{~mm}$ prosome length and the larger at between $0.7 \mathrm{~mm}$ (inshore) and $1.0 \mathrm{~mm}$ (midshelf). The most abundant size class(es) of copepods in the water column was largely ignored at
Table 5. Sagitta friderici and S. tasmanica. Size (prosome length) and species distribution of copepods in diets, and in the water column at the inshore station during the night of 17 to 18 February 1991. Data are the sum of the size distributions at each (sampled) depth stratum multiplied by the proportion of the population occupying that stratum

\begin{tabular}{|c|c|c|c|}
\hline $\begin{array}{l}\text { Size class } \\
(\mathrm{mm})\end{array}$ & S. friderici & S. tasmanica & Ambient \\
\hline 0.1 & 0.02 & 0 & 0 \\
\hline 0.2 & 0.54 & 3.39 & 0 \\
\hline 0.3 & 16.04 & 1.23 & 0.60 \\
\hline 0.4 & 5.45 & 7.29 & 1.35 \\
\hline 0.5 & 8.06 & 11.24 & 29.28 \\
\hline 0.6 & 10.17 & 14.10 & 19.87 \\
\hline 0.7 & 21.02 & 46.31 & 16.34 \\
\hline 0.8 & 10.55 & 9.59 & 12.86 \\
\hline 0.9 & 3.89 & 0.62 & 2.63 \\
\hline 1.0 & 4.56 & 0 & 1.73 \\
\hline 1.1 & 1.09 & 0 & 1.45 \\
\hline 1.2 & 2.26 & 2.80 & 1.92 \\
\hline 1.3 & 1.02 & 0 & 2.85 \\
\hline 1.4 & 2.11 & 0 & 1.10 \\
\hline 1.5 & 1.15 & 0 & 0.80 \\
\hline 1.6 & 2.00 & 0 & 1.60 \\
\hline 1.7 & 1.96 & 0 & 1.73 \\
\hline 1.8 & 4.69 & 0 & 1.69 \\
\hline 1.9 & 2.57 & 0.62 & 0.87 \\
\hline 2.0 & 1.46 & 2.80 & 0.53 \\
\hline 2.1 & 0.49 & 0 & 0.63 \\
\hline 2.2 & 0.02 & 0 & 0.09 \\
\hline \multicolumn{4}{|l|}{ Taxon } \\
\hline Oithona spp. & 20.38 & 10.35 & 51.70 \\
\hline Small calanoids & 40.17 & 80.35 & 32.60 \\
\hline $\begin{array}{l}\text { Centropages } \\
\text { brachiatus }\end{array}$ & 18.45 & 0 & 4.40 \\
\hline Metridia lucens & 1.08 & 0 & 7.60 \\
\hline Large calanoids & 19.92 & 9.30 & 3.70 \\
\hline $\mathrm{N}$ & 1180 & 134 & \\
\hline
\end{tabular}

both stations, and falls in the trough between the 2 preferred modes. While it might appear that copepods of $0.3 \mathrm{~mm}$ length were strongly selected for (because of their rarity in the water column), this result is likely to be artifactual and reflect the escapement of (such) small copepods through the $200 \mu \mathrm{m}$ mesh of the net (see e.g. Pillar 1984). Inshore, copepods of the larger prosome length class preferred by $S$. friderici belonged almost exclusively to 'small calanoids', and at the midshelf station to Centropages brachiatus. Small calanoids were taken at approximately ambient proportions inshore (Table 5) both by species and size class (0.6 to $0.8 \mathrm{~mm}$ prosome length). On the other hand, $C$. brachiatus (the species) occurred at significantly greater proportions in the diet of $S$. friderici than it did in the water column, at both stations (Tables $5 \&$ 6 ) but the size class ( 0.8 to $1.3 \mathrm{~mm}$ prosome length) was preferred only at the midshelf station. This reflects the 
Table 6. Sagitta friderici and S. tasmanica. Size (prosome length) and species distribution of copepods in chaetognath diets, and in the water column at the midshelf station during the night of 20 to 21 February 1991. Data are the sum of the size distributions at each (sampled) depth stratum multiplied by the proportion of the population occupying that stratum

\begin{tabular}{|c|c|c|c|}
\hline $\begin{array}{l}\text { Size class } \\
(\mathrm{mm})\end{array}$ & S. friderici & S. tasmanica & Ambient \\
\hline 0.1 & 0 & 0 & 0 \\
\hline 0.2 & 0 & 0 & 0 \\
\hline 0.3 & 6.88 & 0.16 & 0 \\
\hline 0.4 & 2.94 & 0 & 2.93 \\
\hline 0.5 & 0 & 1.15 & 28.85 \\
\hline 0.6 & 1.01 & 0.51 & 11.95 \\
\hline 0.7 & 3.48 & 3.11 & 25.81 \\
\hline 0.8 & 7.42 & 4.25 & 16.78 \\
\hline 0.9 & 22.64 & 7.88 & 4.14 \\
\hline 1.0 & 23.57 & 29.56 & 5.75 \\
\hline 1.1 & 9.43 & 19.56 & 4.66 \\
\hline 1.2 & 12.29 & 18.29 & 0.71 \\
\hline 1.3 & 5.41 & 5.32 & 0.75 \\
\hline 1.4 & 2.47 & 1.60 & 0.73 \\
\hline 1.5 & 0 & 0.63 & 1.03 \\
\hline 1.6 & 0 & 0.83 & 0 \\
\hline 1.7 & 0 & 0.79 & 0.02 \\
\hline 1.8 & 0 & 1.29 & 0 \\
\hline 1.9 & 0 & 2.44 & 0 \\
\hline 2.0 & 0 & 1.76 & 0 \\
\hline 2.1 & 0 & 0 & 0 \\
\hline 2.2 & 0 & 0.65 & 0 \\
\hline \multicolumn{4}{|l|}{ Taxon } \\
\hline Oithona spp. & 9.84 & 0.79 & 14.41 \\
\hline Small calanoids & 9.35 & 5.29 & 42.89 \\
\hline $\begin{array}{l}\text { Centropages } \\
\text { brachiatus }\end{array}$ & 68.55 & 81.00 & 32.92 \\
\hline Metridia lucens & 0 & 0.32 & 2.03 \\
\hline Large calanoids & 12.26 & 12.60 & 7.75 \\
\hline$N$ & 76 & 546 & \\
\hline
\end{tabular}

fact that $C$. brachiatus dominated the ambient size class at the midshelf station whereas Metridia lucens dominated inshore (but was taken at much lower than ambient proportions).

The elevated presence of Centropages brachiatus in the diet of Sagitta friderici was noticeable at all depths sampled (although only the upper- and lower-most layers are shown in Table 1). Because of the surfaceliving nature of this copepod (De Decker 1984), its relatively high abundance in the chaetognaths collected from deep water suggests one of two things. Either some $S$. friderici were feeding at shallower depths, or $S$. friderici were feeding in water deeper than $50 \mathrm{~m}$ but individual chaetognaths were very strongly selecting for the species $C$. brachiatus. The former is in keeping with the evidence presented above regarding DVM and feeding (see also Pearre 1973).

\section{Sagitta tasmanica}

The size range and frequency distribution of Sagitta tasmanica at the 2 stations were markedly different from each other (Fig. 5) (as Gibbons 1992 ${ }^{\mathrm{l}}$ ). The modal size of the population inshore was 7 to $9 \mathrm{~mm}$, while at the midshelf station it was 14 to $15 \mathrm{~mm}$. At the inshore (but not midshelf) station there was also a shift in the size distribution of the population with increasing depth (Fig. 5), to include a greater proportion of smaller individuals. This ontogenetic layering was also partially observed by Gibbons (1992).

Sagitta tasmanica was generally more abundant at the inshore than midshelf station. There were no significant differences in chaetognath abundance over the diel cycle at either station (Fig. 6) indicating that, as with $S$. friderici, few individuals were migrating to beyond the deepest depth sampled. Despite this, DVM was not clear at either station (Fig. 6) and there were no significant differences in the mean depth occupied during the day $(41.36 \pm 2.12 \mathrm{~m}$ inshore, $47.15 \pm 9.06 \mathrm{~m}$ midshelf) or night $(37.29 \pm 2.74 \mathrm{~m}, 46.34 \pm 7.25 \mathrm{~m}$ respectively) $(p<$ $0.01)$. On more detailed inspection, however, it is clear that populations at both stations did not remain static (Fig. 7). The bulk of the S. tasmanica population inshore was situated in the middle and deeper layers of the water column, but individuals moved progressively into the upper $20 \mathrm{~m}$ during the night, to peak at just before dawn (Fig. 7A), Populations at the midshelf station (Fig. 7C), by contrast, were to be found in the upper $40 \mathrm{~m}$ throughout the $24 \mathrm{~h}$. S. tasmanica 'peaked' in the upper $40 \mathrm{~m}$ at noon and moved to gradually deeper depths with nocturnal progression, before moving back to the surface the following day.

Copepods formed over $99 \%$ of the diet of Sagitta tasmanica, and cannibalism occurred in only 3 of the 1120 specimens examined at the inshore station and in 1 of the 825 individuals at the midshelf station. There was no relationship between the number of prey eaten and chaetognath length $(p>0.05)$, but there was a positive correlation between the size of predator and prey (Table $2, \mathrm{p}<0.01)$. The mean number of copepods eaten by chaetognaths at the midshelf station was greater than that at the inshore station (as Gibbons 1992) with up to 9 prey items being recovered from a single individual (Table 3). Single prey items otherwise accounted for

\footnotetext{
It should be pointed out that the size distributions of Sagitta tasmanica presented in Gibbons (1992; Fig. 3, p. 254) were based on individuals whose lengths were over-measured by a factor of 1.2. Thus the modal size of offshore populations was not 18 to $20 \mathrm{~mm}$ as stated but rather 15 to $17 \mathrm{~mm}$. Likewise the modal length of the inshore population was not 14 to 16 but 11 to 13 . The maximum size attained was not $24 \mathrm{~mm}$ but $20 \mathrm{~mm}$. None of the relationships presented are otherwise affected
} 

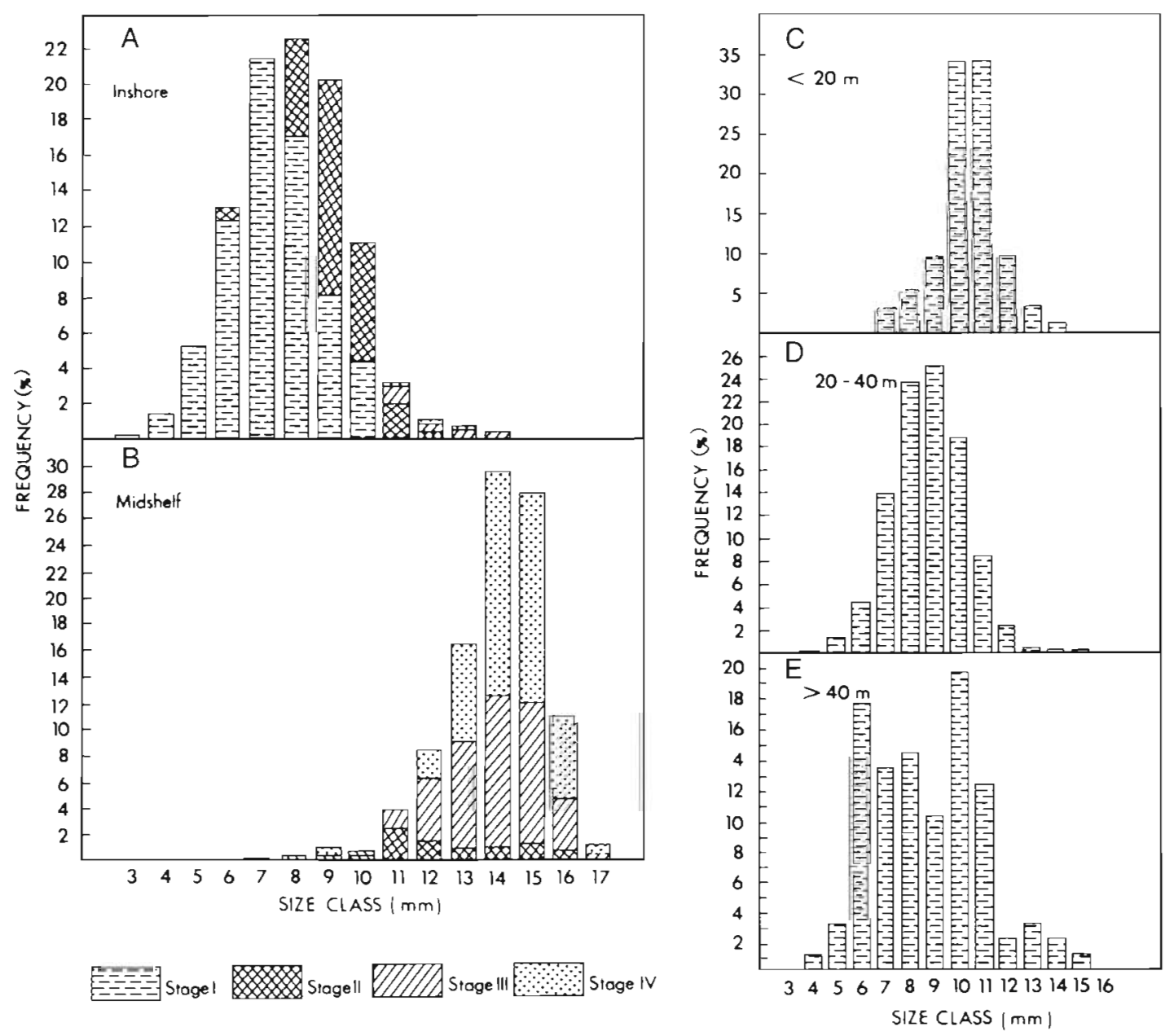

Fig. 5. Sagitta tasmanica. Length:frequency (as percent) plots of populations at the (A) inshore and (B) midshelf stations. (C, D, E) Changes in the size structure of the inshore population with depth. The relationship between chaetognath length and the stage of ovarian development is superimposed in (A) and (B)

$94 \%$ and $62 \%$ of the diet of $S$. tasmanica at the inshore and midshelf stations respectively (Table 3 ).

Although Sagitta tasmanica had the remains of copepods in its gut throughout the $24 \mathrm{~h}$ of detailed study at both stations (Fig. 4), the mean number of copepods recovered from each chaetognath was higher during the night $(0.25 \pm 0.02$ inshore, $1.08 \pm 0.06$ midshelf $)$ than during the day $(0.19 \pm 0.02$ inshore, $0.41 \pm 0.04$ midshelf). There were no significant differences in the numbers of copepods eaten by chaetognaths from the different depth strata sampled by day (Table 4), but significantly more prey were recovered from individuals collected in the surface than deep water at night, at both stations (Table 4). Just as the average number of copepods recovered from chaetognath guts generally increased with nocturnal progression (Fig. 4), so too did the number recovered from individuals in deep water (Fig. 7). In both instances this trend would appear to reflect the movement of $S$. tasmanica from the copepodrich surface waters into the deeper layers (Fig. 7).
Sagitta tasmanica ate a relatively broad size range of prey at both stations 10.1 to $2.0 \mathrm{~mm}$ prosome length inshore, 0.3 to $2.2 \mathrm{~mm}$ midshelf). The incorporation of large prey into the diet of chaetognaths at the midshelf station may be attributed to the larger individual size of chaetognaths at that station. Unlike the size distribution of prey consumed by $S$. friderici, that observed for S. tasmanica (Tables 5 \& 6) was unimodal and peaked at $0.7 \mathrm{~mm}$ prosome length inshore and between 0.9 and $1.2 \mathrm{~mm}$ at the midshelf station. Again, the larger size of preferred copepod at the midshelf station can be partly attributed to the larger chaetognath size at the midshelf station. At the inshore station copepods belonging to the modal size class were mostly small calanoids, which were heavily selected for (by size and species) (Tables $5 \& 6$ ), whilst at the midshelf station they were almost exclusively Centropages brachiatus (as Gibbons 1992), which were also heavily selected for, by species and size. The presence of $C$. brachiatus at disproportionate levels (rela- 


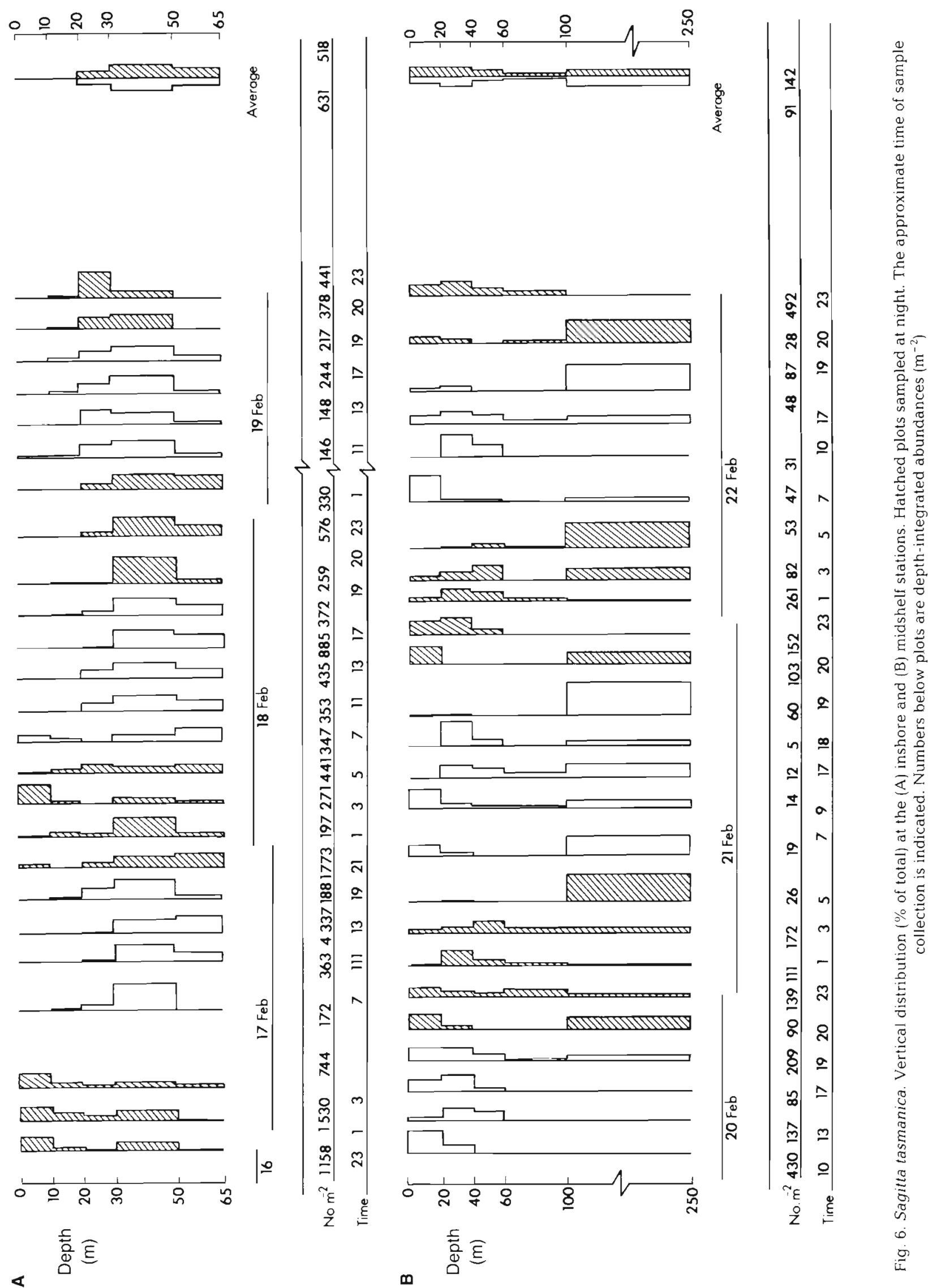



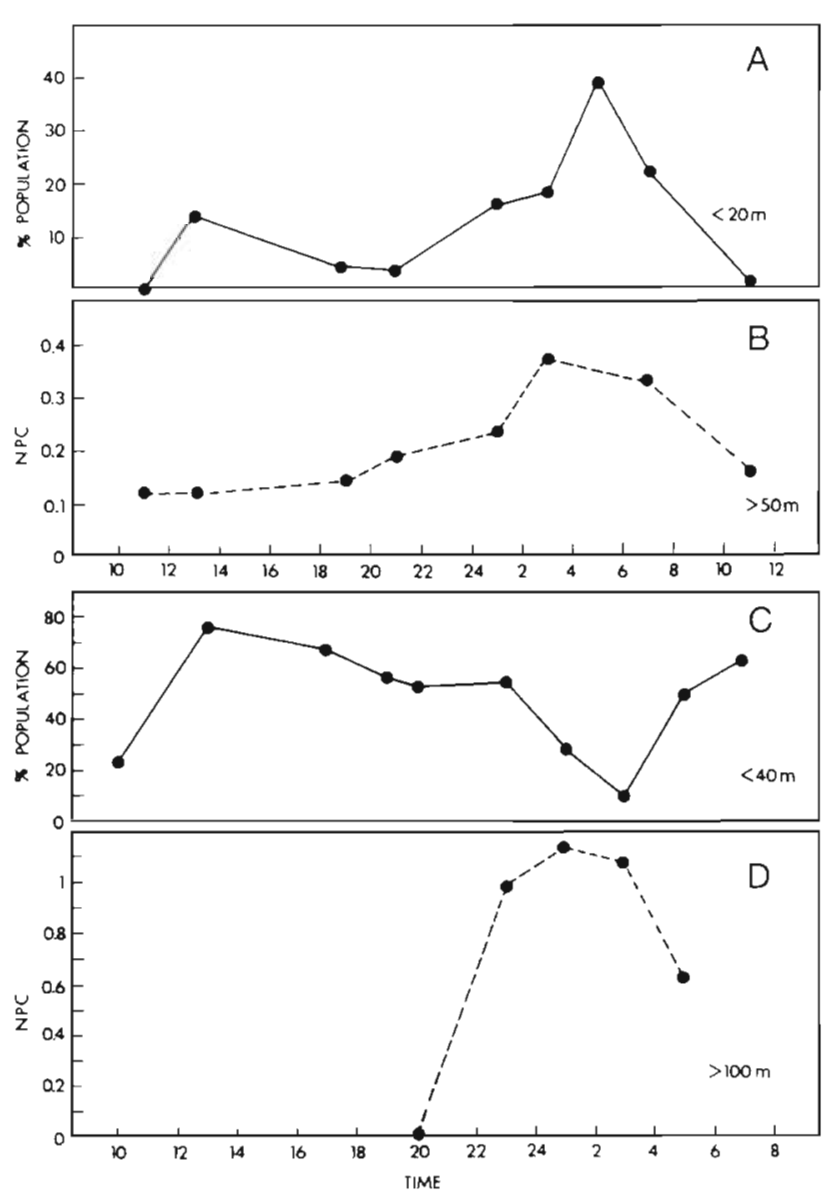

Fig. 7. (A, C) Proportion of Sagitta tasmanica in the upper (A) $20 \mathrm{~m}$ at the inshore station between 17 and 18 February 1991, and (C) $40 \mathrm{~m}$ at the midshelf station between 20 and 21 February 1991. (B, D) Mean number of copepods recovered from chaetognath guts in deep water at the $(B)$ inshore and (D) midshelf stations over the same periods

tive to the water column) in the guts of deep collected $S$. tasmanica at night (Table 1) indicates prior feeding at more superficial depths, and supports the evidence presented earlier on vertical migration.

\section{DISCUSSION}

There was no significant difference in the mean depth occupied during the day or night by either Sagitta friderici or S. tasmanica. Although this suggests that neither chaetognath displayed DVM, the mean depth occupied by day (or night) conveys no information on changes in distribution throughout the day (or night), and masks such variable processes as midnight-sinking (Simard et al. 1985). Even by following changes in mean depth it is possible to miss the more subtle, asynchronous migrations of individuals within populations (e.g. Pearre 1973, Gibbons 1993). By using tracers of surface feeding (in this case total copepods and Centropages brachiatus), however, it is clear that each species of chaetognath was exhibiting DVM. And much of their populations occurred in the surface waters at some stage during the night. Otherwise there was no constancy of pattern between species or station, and little agreement with previous accounts. For example, Stuart \& Verheye (1991) also observed $S$. friderici to exhibit midnight-sinking at an inshore station in St Helena Bay (South Africa) during winter. In contrast to this study, on the other hand, Gibbons (1992) observed $S$. tasmanica during spring in the midshelf region of the southern Benguela to exhibit very pronounced and rapid movement from deep water to the surface at dusk. It must be stressed that such constancy of pattern should not be expected in DVM because of the very many factors which complicate observations and their interpretation (Pearre 1979). What does appear to be consistent between observations, however, is that $S$. friderici occurs at shallower depths than $S$. tasmanica, throughout $24 \mathrm{~h}$ and over many $\mathrm{km}$ of the continental shelf $(p<0.01)$.

Greater prey recoveries were made from both species of chaetognath obtained from the surface than from deep water at night. This suggests that individuals were feeding at the copepod maxima, and when considered with the generally greater densities of chaetognaths in the surface at night, explains the nocturnal feeding rhythms observed. Peaks in copepod recoveries from chaetognaths in deep water were generally made after those in the surface, suggesting the subsequent downward movement of individuals to deeper water to digest their food (as Pearre 1973). Nocturnal feeding by chaetognaths is frequently observed (Szyper 1978, Sullivan 1980, Sameoto 1987), even in the absence of clear DVM (e.g. Pearre 1974, but see also Pearre 1973), and appears to vary seasonally and with changes in the ambient food environment (Rakusa-Suszczewski 1969, Øresland 1987). Of interest here too is an apparent segregation in feeding intensity between the species. Feeding maxima were observed earlier in the night for Sagitta friderici (as also Stuart \& Verheye 1991) than they were for S. tasmanica.

The diets of both species of chaetognath were comprised almost exclusively of copepods, which is no surprise considering copepods were the dominant ambient prey type. Such is the norm for chaetognaths (see review of Feigenbaum \& Maris 1984). Nor is the observation that prey size increases with predator size anything new (Reeve \& Walter 1972, Pearre 1980). There is generally a positive relationship both between predator size and prey size, and between predator size and prey size range, which results in a specific (Pearre 
1980) window of 'preferred' prey size. Changes in the size of this window reflect not only changes in the size structure of the chaetognath population, however, but also in the ambient prey spectra (and its estimation). Interpretations of size 'selection' are not easy, as the absence of a prey size class in the diet of a chaetognath may simply reflect the absence or rarity of that size class in the water column (Feigenbaum 1979 in Pearre 1980) rather than any response to that size class as such. Thus it is possible to interpret the shift in size of the preferred prey eaten by Sagitta tasmanica from the inshore to the midshelf station in terms of both a shift in chaetognath and prey size. That there is a specific change in preferred prey eaten by $S$. tasmanica (small calanoids were strongly selected for inshore but against at the midshelf station) reflects the change in species-size class structure of the water column. The larger size of $S$. tasmanica (midshelf) than $S$. friderici is similarly reflected in the larger size of preferred prey (as Rakusa-Suszczewski 1969).

\section{Guild structure and resource partitioning}

In 'climax' marine ecosystems, such as the North Pacific Gyre, samples of zooplankton separated by many hundreds of kilometres and taken many months apart show a striking degree of similarity (McGowan \& Walker 1979, 1985), in terms of both their high diversity and their near constant structure. Congeneric species and guild-members show pronounced partitioning of vertical space and trophic resources (Ambler \& Miller 1987, Hopkins et al. 1989, Flock \& Hopkins 1992, Hopkins \& Gartner 1992). Because oceanic biomass across the trophic spectra is low, such behaviours mitigate against interspecific competition, and have evolved primarily as a result of prolonged environmental stability. Zooplankton assemblages in upwelling areas, by contrast, are characterised by low diversity (De Decker 1984, Pillar et al. 1992, Verheye et al. 1992). There is often little similarity between samples separated by a few kilometres and taken only days apart (McGowan \& Walker 1985). The reason for this is that upwelling areas are oceanographically dynamic and exhibit significant physical heterogeneity (references in Richards 1981, Payne et al. 1987, 1992). Few species have the necessary adaptations to persist, although those that do so may be abundant (e.g. Pillar et al. 1992, Verheye et al. 1992).

In the light of the physical dynamics of upwelling ecosystems and their high productivity, it is perhaps thought that the evolution of interspecific behaviours allowing co-existence has been unnecessary; i.e. in contrast to climax systems, zooplankton assemblages are structured by physical rather than biological processes. From the data presented here and that collected elsewhere (Fig. 8), however, it would appear that Sagitta friderici and $S$. tasmanica are segregated along a number of niche axes in the southern Benguela upwelling region. And this is reminiscent of resource partitioning (Schoener 1974, 1986, Longhurst 1985). Traditionally, emphasis in studies of resource partitioning is placed on sibling species (Schoener 1986). There have been a number of ecological studies on sympatric species of chaetognaths which explored differences in diet (Rakusa-Suszczewski 1969, Stone 1969, Pearre 1974, 1976, Sullivan 1980, Øresland 1987, 1990) and vertical distribution (Russell 1933, Pearre 1974, Sullivan 1980 , Sameoto 1987). ${ }^{2}$ Yet, with the exception of a comment by Rakusa-Suszczewski (1969, p. 229) none of these authors have attempted to interpret their findings in terms of community structure. The reason for this may be the difficulty of imagining any meaningful interaction between few species in a large, 3-dimensional environment that may be fluctuating in a stochastic manner, and in which food is generally considered abundant. But how valid are these reasons and is it possible to interpret the results presented here in terms of resource partitioning?

Despite the productivity of pulsed upwelling regions (Cushing 1971) there is a significant mismatch in time and space between primary and secondary production, which is reflected in a 'relatively' low copepod biomass and fish production (Hutchings 1992). The net result is that much phytoplankton production enters sedimentary and micro-heterotrophic pathways rather than mesozooplankton (Brown et al. 1991, Hutchings et al. 1991). Furthermore, large areas of the southern Benguela upwelling region are dominated by nano-phytoplankton for much of the year (Hutchings 1992). During prolonged periods of quiescence and mismatch, and in areas dominated by nano-phytoplankton, copepod production can be depressed (Verheye et al. 1992) and copepod starvation may ensue (Attwood \& Peterson 1989). By implication then, copepods (of any one size class) may at times be scarce, and this could have resulted in intense interspecific competition for a common prey size.

If we accept that food may have been, and can be, limiting then the evolution of partitioning behaviours amongst chaetognaths requires both a persistence to guild structure and sufficient time. The diversity and abundance in nearshore assemblages tend to be re-

\footnotetext{
${ }^{2}$ The segregation of feeding time has also been observed (e.g. Roger 1973), yet this need not reflect resource partitioning and may simply be the result of differential digestion time and hence the accumulation of prey. Alternatively, it may reflect the movement of a migrating prey field, if guild members are vertically segregated (as Barange et al. 1991)
} 

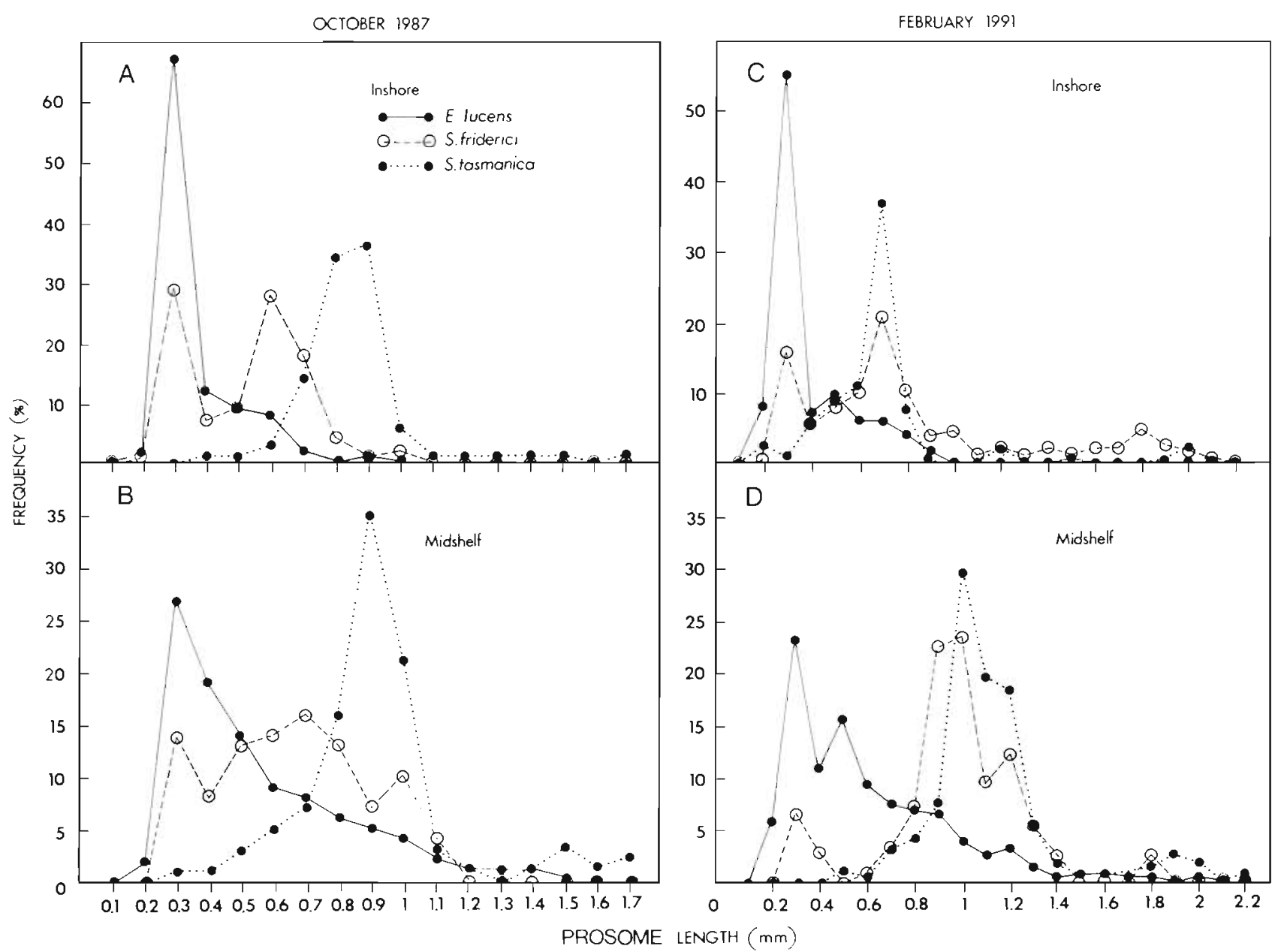

Fig. 8. Size-frequency distribution of copepods recovered from Sagitta friderici, S. tasmanica and Euphausia lucens collected in St Helena Bay during (A, B) October 1987 and (C, D) February 1991. Data in (C) and (D) from Gibbons (1993) (E. lucens) and in (A) and (B) from Gibbons (1992) (S. tasmanica), Gibbons \& Stuart (in press) (S. friderici) and Gibbons et al. (1991b) (E. lucens)

duced during active upwelling, because surface water is moved offshore by Ekman transport, and it is replaced by newly upwelled water of low species richness. During relaxation and onshore water flow, on the other hand, there is a concomitant increase in species richness as neritic assemblages are supplemented with oceanic species. Despite this difference, however, nearshore zooplankton communities are still identifiable irrespective of the state of upwelling (Macpherson 1991, Pagés et al 1991, Pagés 1992). There are several reasons for this. Oceanic water tends to supplement the nearshore assemblage with rare species during relaxation. Neritic species are not necessarily lost from the system during upwelling, and are often returned during wind reversals (Pagés et al. 1991, Pagés 1992). And the upwelled water itself contains the dominant species characteristic of the nearshore region, i.e those forms which perform (ontogenic) vertical migration to take advantage of the various long-shore and cross shelf water movements in their population maintenance (Hutchings 1988, Pillar et al. 1992, Verheye et al. 1992). Thus there is an underlying persistence to the 'core' structure of nearshore assemblages irrespective of the state of upwelling. While shelf-upwelling ecosystems are generally considered to be young ecosystems (geologically), it is thought that the Benguela ecosystem evolved at some time between the Late Miocene and Early Pliocene (Shannon 1985). During the ice-age of the Late Pleistocene in the southern Benguela, the area falling within the $200 \mathrm{~m}$ isobath was approximately $32 \%$ bigger than it is today (Miller 1990, Hutchings 1992). The offshore bathymetry would have been steeper than it is at present and this may have led to more intense upwelling. As both Sagitta friderici and $S$. tasmanica, however, are essentially cold water species they are likely to have been abundant (then as now). Rates of evolutionary change are not known for zooplankton, but it would appear that there may have been several million years of 'persistent' 
structure which may have allowed partitioning to evolve between 'core' members.

Competition, per se, is very difficult to demonstrate (see e.g. Underwood 1986) and one is more often than not left with patterns on which to base conclusions (but see Connor \& Simberloff 1984, Gilpin \& Diamond 1984). This is a especially a problem in the pelagic environment, because of the difficulties involved in detailed experimentation, and more so in the marine than in the limnetic (e.g. DeMott 1989). For example, it is not possible to observe the behaviours of the different species in the southern Benguela in isolation from each other, as they appear to co-occur throughout the nearshore area. However, no attempt is made here to suggest that these species are currently competing with each other. Rather, it is suggested that historic processes of competition may have led to the regular partitioning of resources currently observed. Hutchinsonian Ratios $(1: 1.3)$ (Hutchinson 1959) are frequently used by limnetic (Hutchinson 1967) and terrestrial (Toft 1985) ecologists to infer resource partitioning from size differences between guild members or congeners. Their application to the marine pelagic has met with limited success, especially with regard to herbivorous copepods, as size and food selection are not necessarily related (Mullin 1967). Food and size do appear to be related in the Chaetognatha, both interspecifically and ontogenically (Pearre 1980). It should be noted too, that the cross-shelf distributions of Sagitta friderici and $S$. tasmanica differ: large $S$. friderici $(11.5 \mathrm{~mm})$ and small $S$. tasmanica $(8 \mathrm{~mm})$ inshore and small $S$. friderici $(11 \mathrm{~mm})$ and large $S$. tasmanica $(14.5 \mathrm{~mm})$ in the midshelf region (as also Gibbons \& Stuart in press). Size ratios between the two are approximately $1: 1.3$ which would suggest that Hutchinsonian Ratios may be applicable to chaetognaths.

Alternative explanations for biological pattern of this type include reproductive isolation, predation and resource specialisation (Longhurst 1985, Schoener 1986). As it is thought that the 2 species of chaetognath are from different species-complexes or genera (Bieri 1991) the former can possibly be discounted (but see Kapp 1993). Although predators on zooplankton are as diverse in their feeding mode as they are in their taxonomy, most are opportunistic, size selective filteror particulate-feeders (e.g. James \& Findlay 1989, Hopkins \& Gartner 1992, van der Lingen 1994). Few specialise in prey by species so predation can be disregarded as an explanation for the observed pattern. Likewise, as both species of chaetognath have the same method of prey capture and the same sensors (Bone \& Goto 1991) at their disposal for detecting prey, resource specialisation can also be discounted. These results, if interpreted as evidence of resource partitioning, suggest that there may be more biological struc- ture to the zooplankton communities of physically driven upwelling ecosystems than previously thought.

No discussion of trophic partitioning amongst primary carnivores in the southern Benguela would be complete without reference to the krill Euphausia lucens. This euphausiid represents approximately $50 \%$ of totai zooplankton biomass in the region (Pillar et al. 1992). It is a facultative carnivore whose diet is a reflection of the quantitative and qualitative food environment (Pillar et al. 1992). When chlorophyll concentrations are low, or phytoplankton is of a poor quality $E$. lucens places a pronounced emphasis on carnivory to meet metabolic demands (Stuart 1989, Stuart \& Pillar 1990, Gibbons et al. 1991a, b, Stuart \& Huggett 1992). When feeding carnivorously, krill prey almost exclusively on copepods, so that lateral carbon transfer within the guild is negligible (Gibbons et al. 1992). Cnidarians and ctenophores, and amphipods and decapods are not included amongst primary carnivores because they are not always present in samples and they occupy a trophic guild above that of chaetognaths and euphausiids. A comparison of the diets of the 2 chaetognaths with E. lucens (Fig. 8) reveals minimal trophic overlap, because krill feed almost entirely on small copepods. Although it is tempting to interpret these results (under conditions of low chlorophyll) in terms of resource partitioning, chaetognaths are specialist carnivores (Feigenbaum \& Maris 1984) whilst euphausiids of the genus Euphausia appear to be primarily filter-feeding herbivores (Roger 1973) whose feeding appendages can also be used to catch small, slow-moving prey (Mauchline \& Fisher 1969). Thus, although euphausiids in multispecies assemblages may partition copepod food resources (Barange et al. 1991, Roger 1973, 1975), the apportionment of prey with chaetognaths must be seen in light of resource specialisation.

Acknowledgements. I thank the officers and crew of the F.R.S. 'Africana' for their full assistance during the cruise. I am greatly indebted to numerous of my colleagues for their help with sampling, especially S. Payne, E. Le Roux and A. Polito for counting the copepod samples. I also thank G. M. Branch, W. Peterson, L. Hutchings, G. Pitcher, H. Verheye, J. Huggett and $C$. van der Lingen for their valuable comments on and discussion of parts of this manuscript. In this respect also, the 3 anonymous referees are gratefully acknowledged. I am grateful to members of the reprographics unit (SFRI) for their assistance with the preparation of figures. Financial assistance was provided by the Benguela Ecology Programme of the Foundation for Research and Development.

\section{LITERATURE CITED}

Ambler, J. W., Miller, C. B. (1987). Vertical habitat-partitioning by copepodites and adults of subtropical oceanic copepods. Mar. Biol. 94: 561-577 
Attwood, C. G., Peterson, W. T. (1989). Reduction in fecundity and lipids of the copepod Calanus australis (Brodskii) by strongly pulsed upwelling. J. exp. mar Biol. Ecol. 129: $121-131$

Barange, M., Gibbons, M. J., Carola, M. (1991). Diet and feeding of Euphausia hanseni and Nematoscelis megalops (Euphausiacea) in the northern Benguela Current: ecological significance of vertical space partitioning. Mar Ecol. Prog. Ser 73: 173-181

Bieri, R. (1991). Systematics of the Chaetognatha. In: Bone, Q, Kapp, H., Pierrot-Bults, A. C. (eds.) The biology of chaetognaths. Oxford Science Publications, Oxford, p. $122-136$

Bone, Q., Goto, $T$ (1991). The nervous system. In: Bone, Q. Kapp, H., Pierrot-Bults, A. C. (eds.) The biology of chaetognaths. Oxford Science Publications, Oxford p. 18-31

Brown, P. C., Painting, S. J., Cochrane, K. L. (1991). Estimates of phytoplankton and bacterial biomass and production in the northern and southern Benguela ecosystems. S. Afr. J mar. Sci. 11: $537-564$

Connor, E. F., Simberloff, D. (1984). Neutral models of species' co-occurrence patterns. In: Strong, D. R., Simberloff D., Abele, L. G., Thistle, A. B. (eds.) Ecological communities: conceptual issues and the evidence. Princeton University Press, Princeton, NJ, p. 316-331

Cushing, D. H. (1971). Upwelling and the production of fish Adv. mar. Biol. 9: 255-334

De Decker, A. H. B. (1984). Near-surface copepod distribution in the south-western Indian and south-eastern Atlantic Ocean. Ann. S. Afr. Mus. 93: 303-370

DeMott, W. R. (1989). The role of competition in zooplankton succession. In: Sommer, U. (ed.) Plankton ecology Springer-Verlag, Berlin, p. 195-252

Feigenbaum, D. L. (1991). Food and feeding behaviour In: Bone, Q., Kapp, H., Pierrot-Bults, A. C. (eds.) The biology of chaetognaths. Oxford Science Publications, Oxford p. 45-54

Feigenbaum, D. L., Maris, R. C. (1984). Feeding in the chaetognatha. Oceanogr. mar. Biol. A. Rev. 22: 343-392

Flock, M. E., Hopkins, T. L. (1992). Species composition, vertical distribution, and food habits of the sergestid shrimp assemblage in the eastern Gulf of Mexico. J. Crust. Biol 12: $210-233$

Gibbons, M. J. (1992). Diel feeding and vertical migration of Sagitta serratodentata Krohn tasmanica Thomson (Chaetognatha) in the southern Benguela. J. Plankton Res. 14: $249-259$

Gibbons, M. J. (1993). Vertical migration and feeding of Euphausia lucens at two $72 \mathrm{~h}$ stations in the southern Benguela upwelling region. Mar. Biol. 116: 257-268

Gibbons, M. J., Barange, M., Pillar, S. C. (1991a). Vertical migration and feeding of Euphausia lucens (Euphausiacea) in the southern Benguela. J. Plankton Res. 13: $473-486$

Gibbons, M. J., Pillar, S. C., Stuart, V. (1991b). Selective carnivory by Euphausia lucens. Cont. Shelf Res. 11: 625-640

Gibbons, M. J., Stuart, V (in press). Feeding and vertical migration of the chaetognath Sagitta friderici (RitterZáhony, 1911) in the southern Benguela during spring 1987, with notes on seasonal variability of feeding ecology. S. Afr. J. mar. Sci. 14

Gibbons, M. J., Stuart, V., Verheye, H. M. (1992). Trophic ecology of carnivorous zooplankton in the Benguela. S. Atr. J. mar. Sci. 12: 421-437

Gilpin, M. E., Diamond, J. M. (1984). Are species co-occurrences on islands non-random, and are null hypotheses useful in community ecology. In: Strong. D. R., Simberloff,
D., Abele, L. G., Thistle, A. B. (eds.) Ecological communities: conceptual issues and the evidence. Princeton University Press, Princeton, NJ, p. 297-315

Grant, G. C. (1991). Chaetognatha from the central and southern Middle Atlantic Bight: species composition, temperature-salinity relationships, and interspecific associations. Fish. Bull. U.S. 89: 33-40

Heydorn, A. E. F. (1959). The Chaetognatha off the west coast of the Union of South Africa. July 1954 - June 1955. Invest] Rep. Div. Fish. S. A.fr. 36: 1-56

Hopkins, T L., Gartner, J. V. Jr (1992). Resource-partitioning and predation impact of a low-latitude myctophid community. Mar. Biol. 114: 185-197

Hopkins, T L., Gartner, J. V. Jr, Flock, M. E. (1989). The caridean shrimp (Decapoda: Natantia) assemblage in the mesopelagic zone of the eastern Gulf of Mexico. Bull. mar. Sci. 45: $1-14$

Hutchings, L. (1988). Horizontal distribution of mesozooplankton in the southern Benguela Current. Investl Rep. Sea Fish. Res. Inst. S. Afr. 131: 1-70

Hutchings, L. (1992). Fish harvesting in a variable, productive environment - searching for rules or searching for exceptions? S. Afr. J. mar. Sci. 12: 297-318

Hutchings, L., Pillar, S. C., Verheye, H. M. (1991). Estimates of standing stock, production and consumption of meso- and macrozooplankton in the Benguela ecosystem. S. Afr. J. mar. Sci. 11: 499-512

Hutchinson, G. E. (1959). Homage to Santa Rosalia, or Why are there so many kinds of animals? Am. Nat. 93: 145-149

Hutchinson, G. E. (1967). A treatise of limnology, Vol. 2. John Wiley, New York

James, A. G. (1987). Feeding ecology, diet and field-based studies on feeding selectivity of the Cape anchovy Engraulis capensis Gilchrist. S. Afr. J. mar. Sci. 5: 673-692

James, A. G., Findlay, K. P. (1989). Effect of particle size and concentration on feeding behaviour, selectivity and rates of food ingestion by the Cape anchovy Engraulis capensis Gilchrist. Mar. Ecol. Prog. Ser. 50: 275-294

Kapp, H. (1993). Some aspects of chaetognath systematics. In: Moreno, I. (ed.) Proceedings of the Second International Workshop of Chaetognatha, Palma, 1992; Univ. des Illes Beleares, p. $37-43$

Kimmerer, W. J. (1984). Selective predation and its impact on prey of Sagitta enflata (Chaetognatha). Mar. Ecol. Prog. Ser. 15: 55-62

Longhurst, A. R. (1985). Relationship between diversity and the vertical structure of the upper ocean. Deep Sea Res. 32: $1535-1570$

Macpherson, E. (1991). Biogeography and community structure of the decapod crustacean fauna off Namibia (Southeast Atlantic). J. Crust. Biol. 11. 401-415

Mauchline, J., Fisher, L. R. (1969). The biology of euphausiids. Adv. mar. Biol. 7. 1-454

McGowan, J. A., Walker, P. W. (1979). Structure in the copepod community of the north Pacific gyre. Ecol. Monogr. 49: $195-226$

McGowan, J. A., Walker, P. W. (1985). Dominance and diversity maintenance in an oceanic ecosystem. Ecol. Monogr. 55: $103-118$

Miller, D. E. (1990). A southern African Late Quaternary sealevel curve. S. Afr. J. Sci. 86: 456-458

Mullin, M. M. (1967). On the feeding behaviour of planktonic marine copepods and the separation of their ecological niches. Mar. Biol. Ass., India. Symp. Ser (2): 955-964

Øresland, V. (1987). Feeding of the chaetognaths Sagitta elegans and $S$. setosa at different seasons in Gullmarsfjorden, Sweden. Mar. Ecol. Prog. Ser. 39: 69-79 
Øresland, V. (1990). Feeding and predation impact of the chaetognath Eukrohnia hamata in Gerlache Strait, Antarctic Peninsula. Mar. Ecol. Prog. Ser. 63: 201-209

Pagés, F. (1992). Mesoscale coupling between planktonic cnidarian distribution and water masses during a temporal transition between active upwelling and abatement in the northern Benguela system. S. Afr. J. mar. Sci. 12: 41-52

Pagés, F., Verheye, H. M., Gili, J. M., Flos, J. (1991). Shortterm effects of coastal upwelling and wind reversals on assemblages of epiplanktonic cnidarians in the southern Benguela region. S. Afr. J. mar. Sci. 10: 203-212

Payne, A. I. L., Gulland, J. A., Brink, K. H. (1987). The Benguela and comparable ecosystems. S. Afr. J. mar. Sci. 5: 1-957

Payne, A. I. L., Brink, K. H., Mann, K. H., Hilborn, R. (1992). Benguela trophic functioning. S. Afr. J. mar. Sci. 12: $1-1108$

Pearre, S. (1973). Vertical migration and feeding in Sagitta elegans Verrill. Ecology 54: 300-314

Pearre, S. (1974). Ecological studies of three west-Mediterranean chaetognaths. Invest. Pesq. 38: 325-369

Pearre, S. (1976). A seasonal study of the diets of three sympatric chaetognaths. Invest. Pesq. 40:1-16

Pearre, S. (1979). Problems of detection and interpretation of vertical migration. J. Plankton Res. 1: 29-44

Pearre, S. (1980). Feeding by Chaetognatha: the relation of prey size to predator size in several species. Mar. Ecol. Prog. Ser. 3: 125-134

Peterson, W. T., Painting, S. J., Hutchings, L. (1990). Diel variations in gut pigment content, diel vertical migration and estimates of grazing impact for copepods in the southern Benguela upwelling region in October 1987. J. Plankton Res. 12: 259-281

Pierrot-Bults, A. C., Nair, V. R. (1991). Distribution patterns in Chaetognatha. In: Bone, Q., Kapp, H, Pierrot-Bults, A. C. (eds.) The biology of chaetognaths. Oxford Science Publications, Oxford, p. 86-116

Pillar, S. C. (1984). A comparison of the performance of four zooplankton samplers. S. Afr. J. mar. Sci. 2: 1-18

Pillar, S. C., Stuart, V., Barange, M., Gibbons, M. J. (1992). Community structure and trophic ecology of euphausiids in the Benguela ecosystem. S. Afr. J. mar. Sci. 12: 393-409

Rakusa-Suszczewski, S. (1969). The food and feeding habits of Chaetognatha in the seas around the British Isles. Polskie Arch. Hydrobiol. 16: 213-232

Reeve, M. R. (1970). The biology of Chaetognatha I. Quantitative aspects of growth and egg production in Sagitta hispida. In: Steele, J. H. (ed.) Marine food chains. Oliver and Boyd, Edinburgh, p. 168-189

Reeve, M. R., Walter, M. A. (1972). Conditions of culture, food size selection, and the effects of temperature and salinity on growth rate and generation time in Sagitta hispida Conant. J. exp. mar. Biol. Ecol. 9: 191-200

Richards, F. A. (1981). Coastal upwelling. American Geophysical Union, Washington, DC, p. 1-529

Roger, C. (1973). Recherches sur la situation trophique d'un groupe d'organismes pelagigues (Euphausiacea). II. Comportements nutritionnels. Mar. Biol. 18: 317-320

Roger, C. (1975). Rythmes nutritionnels et organisation d'une population de crustaces pelagiques (Euphausiacea). Mar. Biol. 32: $365-378$

Russell, F. S. (1933). On the biology of Sagitta. IV. Observations on the natural history of Sagitta elegans Verrill and Sagitta setosa J. Müller in the Plymouth area. J. mar biol. Ass. U.K. 18: 559-571

Sameoto, D. D. (1987). Vertical distribution and ecologica] significance of chaetognaths in the Arctic environment of Baffin Bay. Polar Biol. 7: 317-328

Schoener, T. W. (1974). Resource partitioning in ecological communities. Science 185: 27-39

Schoener, T. W. (1986). Resource partitioning. In: Kikkawa, J., Anderson, D. J. (eds.) Community ecology: pattern and process. Blackwell Scientific Publications, Oxford, p. $91-126$

Shannon, L. V. (1985). The Benguela ecosystem I. Evolution of the Benguela, physical features and processes. Oceanogr. mar. Biol. A. Rev. 23: 105-182

Simard, Y., Lacroix, G., Legendre, L. (1985). In situ twilight grazing rhythm during diel vertical migrations of a scattering layer of Calanus finmarchicus. Limnol. Oceanogr 30: $598-606$

Sokal, R. R., Rohlf, F. J. (1981). Biometry. W. H. Freeman, New York

Stone, J. H. (1969). The Chaetognatha community of the Agulhas Current: its structure and related properties. Ecol. Monogr. 39: 433-463

Stuart, V. (1989). Observations on the feeding of Euphausia lucens on natural phytoplankton suspensions in the southern Benguela upwelling region. Cont. Shelf Res. 9: $1017-1028$

Stuart, V., Pillar, S. C. (1990). Diel grazing patterns of all ontogenetic stages of Euphausia lucens and in situ predation rates on copepods in the southern Benguela upwelling region. Mar. Ecol. Prog. Ser. 64: 227-241

Stuart, V., Verheye, H. M. (1991). Diel migration and feeding patterns of the chaetognath, Sagitta friderici, off the west coast of South Africa. J. mar. Res. 49: 493-515

Stuart, V., Huggett, J. A. (1992). Prey selection by Euphausia lucens (Hansen) and feeding behaviour in response to a mixed algal and animal diet. J. exp. mar. Biol. Ecol. 164: $117-133$

Sullivan, B. K. (1980). In situ behaviour of Sagitta elegans and Eukrohnia hamata (Chaetognatha) in relation to the vertical distribution and abundance of prey at Ocean Station ' $P$ '. Limnol. Oceanogr. 25: 317-326

Szyper, J. P. (1978). Feeding rate of the chaetognath Sagitta enflata in nature. Estuar. coast. mar. Sci. 7: 567-575

Thiriot, A. (1978). Zooplankton communities in the west African upwelling area. In: Boje, R., Tomczak, M. (eds.) Upwelling ecosystems. Springer-Verlag, Berlin, p. 32-61

Thomson, J. M. (1947). The Chaetognatha of south-eastern Australia. Bull. Counc. Scient. ind. Res. Melb. 222: 1-43

Toft, C. A. (1985). Resource partitioning in amphibians and reptiles Copeia 1: 1-24

Underwood, A. J. (1986). The analysis of competition by field experiments. In: Kikkawa, J., Anderson, D. J. (eds.) Community ecology: pattern and process. Blackwell Scientific Publications, Oxford, p. 240-268

van der Lingen, C. D. (1994). Effect of particle size and concentration on the feeding behaviour of adult pilchard, Sardinops sagax. Mar. Ecol. Prog. Ser 109: 1-13

Venter, G. E. (1969). The distribution of some chaetognaths and their relation to hydrological conditions, with special reference to the South West African region of the Benguela Current. Investl Rep. mar. Res. Lab. S.W. Afr. 16: $1-73$

Verheye, H. M., Hutchings, L., Huggett, J. A., Painting, S. J, (1992). Mesozooplankton dynamics in the Benguela ecosystem, with special reference to the copepod Calanoides carinatus. S. A.fr. J. mar. Sci. 12: 561-584

Zar, J. H. (1984). Biostatistical analysis. Prentice-Hall, Englewood Cliffs, NJ

Manuscript first received: January 26, 1994

Revised version accepted: May 30, 1994 